\title{
PARTISIPASI KELOMPOK TANI DALAM KEGIATAN PENYULUHAN PERTANIAN DI DESA KANONANG LIMA, KECAMATAN KAWANGKOAN BARAT
}

\author{
Mario Victorya Koampa \\ Benu Olfie L.S. \\ Martha M Sendow \\ Vicky R.B. Moniaga
}

\begin{abstract}
The objective of this research is to describe the participation of farmer's group in extension activity. The benefit of this research is to support the knowledge for agricultural extension agent. This research had been conducted for three months from the the preparation to management of report from July to September, 2015 at Kanonang Lima Village Kawangkoan Barat Sub-district, Minahasa Regency. The research uses purposive random sampling of farmer;s group combined with four farmer groups namely Esa Lalan, Esa Ate, Karondoran and Berkat at Kanonang Lima Village Kawangkoan Barat Sub-district. Only two farmer groups that predominantly namely Esa Lalan and Esa Ate farmer groups. Methods of data collection is done by using the primary data. The primary data obtained directly from Esa Lalan and Esa Ate farmer groups using a list of questions. The collecting data had been conducted by using primary data from Esa Lalan and Esa Ate farmer groups. The participation of farmers' group in agricultural activity had been classified as active at planning and conducting stage. The presence of farmer to participate in agricultural extension is needed to be increased.
\end{abstract}

Key words: farmer groups, participation, Desa Kanonang, Minahasa

\begin{abstract}
ABSTRAK
Tujuan penelitian yaitu mendeskripsikan partisipasi kelompok tani dalam kegiatan penyuluhan. Manfaat penelitian ini diharapkan dapat menjadi sumbangan ilmu pengetahuan bagi penyuluh pertanian. Penelitian ini berlangsung selama tiga bulan sejak persiapan sampai penyusunan laporan terhitung dari Bulan Juli sampai September 2015. Penelitian ini dilaksanakan di Desa Kanonang Lima Kecamatan Kawangkoan Barat Kabupaten Minahasa. Penelitian menggunakan metode purposive sampling dari satu gapoktan ada empat kelompok tani yaitu kelompok tani Esa Lalan, Esa Ate, Karondoran dan Berkat yang berada di Desa Kanonang Lima Kecamatan Kawangkoan Barat. Yang diambil hanya dua kelompok tani yang menonjol yaitu kelompok tani Esa Lalan dan kelompok tani Esa Ate. Metode pengumpulan data dilakukan dengan menggunakan dengan data primer. Data primer diperoleh langsung dari kelompok tani Esa Lalan dan kelompok tani Esa Ate menggunakan daftar pertanyaan (kuisioner). Partisipasi Kelompok Tani Terhadap kegiatan penyuluhan pertanian tergolong kategori aktif pada tahap perencanaan, pelaksanaan dan evaluasi. Kehadiran partisipasi petani dalam penyuluhan perlu di tingkatkan.
\end{abstract}

Kata kunci: kelompok tani, partisipasi, Desa Kanonang, Minahasa

\section{PENDAHULUAN}

\section{Latar Belakang}

Partisipasi dalam pembangunan pertanian berperan sebagai jembatan yang menghubungkan antara praktek yang dijalankan oleh petani dengan pengetahuan dan teknologi petani yang selalu berkembang menjadi kebutuhan para petani tersebut (Kartasapoetra,2002). Agar petani dapat melakukan praktek-praktek yang mendukung usaha tani maka petani membutuhkan informasi inovasi dibidang pertanian. Informasi tersebut dapat diperoleh petani antara lain dari PPL (Penyuluh Pertanian Lapang) melalui penyelenggaraan kegiatan penyuluhan pertanian. 
Pemerintah telah mengeluarkan kebijakan untuk merevitalisasi penyuluhan, dan salah satu strategi dalam program tersebut adalah memberdayakan petani Melalui Gapoktan seluruh kekuatan yang dimiliki oleh petani dalam kelompoknya digabungkan untuk menggerakkan kelompok. Dengan kata lain petani di didik untuk lebih mandiri dengan mengandalkan kekuatan mereka sendiri. Selain itu ada yang lebih istimewa dalam program ini, yaitu pemerintah ingin menaikkan status petani melalui kemandirian dan kreativitas mereka, karena Gapoktan akan berstatus hukum yang jelas sehingga memiliki daya tawar lebih tinggi dan diakui secara resmi sebagai suatu kelompok usaha. Gapoktan akan memiliki berbagai bentuk izin usaha, rekening bank, asset, akte notaris, dan lain sebagainya selayaknya perusahaan. Selain itu Gapoktan diharapkan mampu berkembang menjadi organisasi petani yang kuat dan mandiri, sehingga Gapoktan menjadi pemberdayaan petani andalan dari sektor pertanian saat ini (Mushero, 2008).

Adapun di tingkat provinsi, penanggung jawab pengembangan Gapoktan adalah gubernur, sedangkan penanggung jawab operasionalnya dilaksanakan oleh sekretaris Badan Koordinasi Penyuluhan Pertanian Provinsi dan dibantu oleh dinas atau instansi terkait di tingkat provinsi. Sebagai kecamatan penghasil produksi padi terbesar, desa Kanonang lima Kecamatan Kawangkoan Barat Kabupaten Minahasa tentu juga harus memiliki kelembagaan petani yang berkembang dan mandiri agar petani lebih optimal melaksanakan usaha taninya untuk meningkatkan hasil produksinya, salah satunya melalui Gapoktan. desa Kanonang lima Kecamatan Kawangkoan Barat yang memiliki jumlah kelompok tani yaitu sebanyak dua Kelompok Tani.

Keberadaan Gapoktan Di Desa Kanonang Lima Kecamatan Kawangkoan Barat tak luput dari peran penyuluh pertanian yang berada di BP3K (Balai Penyuluhan Pertanian, Perikanan, Dan Kehutanan) Desa Kanonang lima Kecamatan Kawangkoan Barat yang mempunyai tujuan meningkatkan pemberdayaan kelembagaan petani di wilayah Desa Kanonang lima Kecamatan Kawangkoan Barat. Salah satu faktor yang mempengaruhi tingkat perkembangan Gapoktan adalah terlaksananya peran penyuluh pertanian dengan baik. Namun dalam pengembangan Gapoktan tidak selalu berjalan dengan baik masih terdapat beberapa hambatan yang dihadapi dalam pengembangan Gapoktan. Menurut penelitian awal yang dilakukan peneliti di Desa Kanonang lima Kecamatan Kawang- koan Barat, hambatan tersebut baik dari segi kegiatan unit usaha dalam Gapoktan maupun dari penyuluh pertanian dan kebijakan pemerintah yang belum sepenuhnya mendukung perkembangan Gapoktan. Untuk itu diperlukan suatu kajian yang mendalam mengenai peran penyuluh pertanian dalam pengembangan Gapoktan di Desa Kanonang lima Kecamatan Kawangkoan Barat.

\section{Partisipasi Petani}

Pada dasarnya partisipasi didefinisikan sebagai keterlibatan mental atau pikiran dan emosi atau perasaan seseorang di dalam situasi kelompok yang mendorongnya untuk memberikan sumbangan kepada kelompok dalam usaha mencapai tujuan. Keterlibatan aktif dalam berpartisipasi, bukan hanya berarti keterlibatan jasmaniah semata. Partisipasi dapat diartikan sebagai keterlibatan mental, pikiran, dan emosi atau perasaan seseorang dalam situasi kelompok yang mendorongnya untuk memberikan sumbangan kepada kelompok dalam usaha mencapai tujuan serta turut bertanggung jawab terhadap usaha yang bersangkutan.

Partisipasi adalah keterlibatan spontan dengan kesadaran disertai tanggung jawab terhadap kepentingan kelompok untuk mencapai tujuan bersama (Sastroepoetra, 2004), sedangkan Mikkelsen (2003), mendifinisikan partisipasi adalah sukarela oleh masyarakat dalam perubahan yang ditentukannya sendiri.

Partisipasi berbasis masyarakat adalah suatu proses aktif dimana penduduk desa secara langsung ikut serta dalam merencanakan, melaksanakan, dan mengevaluasi proyek atau program pembangunan yang mereka miliki dengan tujuan untuk menumbuhkan kemandiriaannya, meningkatkan pendapatannya dan pengembangan (Porawouw, 2005).

Partisipasi petani merupakan keikutsertaan dari petani baik secara individu maupun secara kelompok dengan penuh kesadaran dan tanggung jawab dalam bidang usaha pertanian. Didalam melaksanakan program penyuluhan pertanian, partisipasi petani sebagai sasaran penyuluhan pertanian merupakan faktor yang sangat penting. Partisipasi tersebut dapat berupa menghadiri pertemuan, mengajukan pertanyaan kepada PPL saat pertemuan penyuluhan. Menurut Van Den Ban dan Hawkins, ditinjau dari segi motivasinya, partisipasi masyarakat terjadi karena :

1. Takut/ terpaksa, partisipasi yang dilakukan dengan terpaksa atau takut biasanya akibat adanya perintah 
yang kaku dari atasan sehingga masyarakat seakan-akan terpaksa untuk melaksanakan rencana yang telah ditentukan.

2. Ikut-ikutan, partisipasi dalam ikut-ikutan hanya didorong oleh rasa solidaritas yang tinggi diantara sesama masyarakat desa, apalagi yang memulai adalah pemimpin mereka, sehingga keikutsertaan mereka bukan karena dorongan hati sendiri, tetapi merupakan perwujudan kebersamaan saja.

3. Kesadaran, partisipasi yang timbul karena kehendak dari pribadi anggota masyarakat. Hal ini dilandasi oleh dorongan yang timbul dari hati nurani sendiri. Partisipasi bentuk yang sesungguhnya sangat diharapkan dapat berkembang dalam masyarakat desa. Dengan adanya partisipasi yang didasarkan atas kesadaran, maka masyarakat dapat diajak memelihara dan meraa memiliki objek pembangunan yang diselengarakan didesa tersebut.

\section{Jenis Partisipasi Kelompok Tani}

Menurut (Sutami, 2009) dikemukakan bahwa jenis-jenis partisipasi meliputi: (a) Tenaga; (b) Pikiran; (c) Pikiran dan tenaga; (d) Keahlian; (e) Barang dan uang. Dari jenis-jenis partisipasi tersebut akan dijelaskan sebagai berikut:

1. Pikiran: pikiran merupakan jenis partisipasi pada level pertama dimana partisipasi tersebut merupakan partisipasi dengan menggunakan pikiran seseorang atau kelompok yang bertujuan untuk mencapai sesuatu yang diinginkan.

2. Tenaga: merupakan jenis partisipasi pada level kedua dimana partisipasi tersebut dengan mendayagunakan seluruh tenaga yang dimiliki secara kelompok maupun individu untuk mencapai sesuatu yang diinginkan.

3. Pikiran dan Tenaga: merupakan jenis partisipasi pada level ketiga dimana tingkat partisipasi tersebut dilakukan bersama-sama dalam suatu kelompok dalam mencapai tujuan yang sama.

4. Keahlian: merupakan jenis partisipasi pada level keempat dimana dalam hal tersebut keahlian menjadi unsur yang paling diinginkan untuk menentukan suatu keinginan.

5. Barang: merupakan jenis partisipasi pada level kelima dimana partisipasi dilakukan dengan sebuah barang untuk membantu guna mencapai hasil yang diinginkan.

6. Uang: merupakan jenis partisipasi pada level keenam dimana partisipasi tersebut menggunakan uang sebagai alat guna mencapai sesuatu yang diinginkan. Biasanya tingkat partisipasi tersebut dilakukan oleh orang-orang kalangan atas.

Keikutsertaan masyarakat adalah sangat penting di dalam keseluruhan proses program. Partisipasi masyarakat dalam program pemberdayaan selayaknya mencakup keseluruhan proses mulai dari awal sampai tahap akhir. Oleh karena itu, partisipasi publik dapat terjadi pada 4 (empat) jenjang, yaitu:

1. Partisipasi dalam tahap proses pembentukan keputusan;

2. Partisipasi dalam tahap pelaksanaan

3. Partisipasi dalam tahap pemanfaatan hasil;

4. Partisipasi dalam tahap evaluasi.

Partisipasi Anggota Kelompok tani dalam kegiatan kelompok tani adalah sebagai berikut :

1. Partisipasi Dalam Pengambilan Keputusan Dalam Perencanaan Kegiatan Dalam Kelompok Tani. Pengambilan keputusan pada kelompok tani mufakat di desa Banua Padang Hilir dengan mengadakan rapat yang mengharuskan seluruh anggota kelompok tani berhadir agar kesepakatan yang ingin dicapai pada pengambilan keputusan dapat di capai. Partisipasi kehadiran anggota kelompok tani mufakat sudah cukup baik, dengan melibatkan seluruh anggota dalam setiap kegiatan rapat-rapat pengambilan keputusan. Perencanaan kegiatan yang biasanya dilakukan masyarakat yaitu untuk merncanakan kegiatan penanaman padi, dari penyemaian, penanaman, pemupukan hingga panen. Selain itu pengambilan keputusan dalam kelompok tani mufakat juga dilakukan jika ingin mencari solusi dari berbagai masalah pertanian yang dihadapi dengan musyawarah yang dilakukan seluruh anggota kelompok tani.

2. Partisipasi Dalam Pelaksanaan Kegiatan Kelompok Tani partisipasi pelaksanaan kegiatan kelompok tani Mufakat di desa banua Padang Hilir selalu di ikuti anggota kelompok tani mufakat dengan aktif. Kegiatan kelompok tani yang dilakukan secara umum yaitu kegiatan Sekolah Lapang, sarana kerjasama antar anggota kelompok tani dan sarana satu kesatuan usaha (unit produksi usaha tani).Kegiatan belajar mengajar pada kelompok tani mufakat dilakukan satu minggu sekali Baik SLPTT (Sekolah Lapang Pengelolaan Tanaman Terpadu) maupun SLPHT (sekolah Lapang Pengelolaan Hama terpadu). Dalam kegiatan sekolah lapang petani dapat saling berinteraksi untuk meningkatkan pengetahuan, 
keterampilan dan sikap serta tumbuh dan berkembangnya kemandirian dalam berusaha tani. Kelompok tani sebagai sarana kerjasama antar anggota kelompok tani dengan harapan agar usaha tani akan lebih efisien, serta lebih mampu menghadapi ancaman, tantangan, hambatan, dan gangguan yang dihadapi kelompok tani sebagai satu kesatuan usaha yang dpat dikembangkan untuk mencapai skala ekonomi, dipandang dari segi kualitas, kuantitas, dan kontinuitas. Secara konseptual peran kelompok tani lebih merupakan suatu gambaran tentang kegiatan kegiatan kelompok tani yang dikelola berdasarkan kesepakatan anggotanya. Peranan kelompok tani akan semakin meningkat apabila dapat menumbuhkan kekuatankekuatan yang dimiliki dalam kelompok itu sendiri untuk dapat menggerakkan dan mendorong perilaku anggotanya kea rah pencapaian tujuan kelompok sehingga kelompok tani tersebut akan berkembang menjadi lebih dinamis. Kelompok tani dapat berkembang secara dinamis jika di dukung oleh seluruh kegiatan yang inisiatif, memiliki daya kreatif, dan tindakan tindakan nyata yang dilakukan oleh seluruh anggota kelompok tani dalam melaksanakan kegiatankegiatan yang telah disepakati bersama.

3. Partisipasi Dalam Pemantauan dan Evaluasi Kegiatan Kelompok Tani partisipasi dalam pemantapan kegiatan kelompok tani mufakat desa Banua Padang Hilir yaitu dengan mengadakan pertemuan kelompok secara rutin, menetapkan agenda pertemuan secara jelas, dalam setiap pertemuan diawali dengan laporan perkembangan keuangan, kelompok dan laporan perkembangan kegiatan, memberi kesempatan kepada semua anggota yang hadir untuk memberikan tanggapan dan pertanyaan-pertanyaan sehubungan dengan laporan perkembangan yang disampaikan, memberi tanggapan positif atas usul dan saran dari setiap anggota kelompok yang hadir, Mendiskusikan setiap kegiatan yang akan dilaksanakan, dengan cara musyawarah dengan anggota kelompok, dan selalu berupaya untuk memperbaiki manajemen keuangan dan manajemen kelompok.

Partisipasi evaluasi kegiatan kelompok tani mufakat yaitu menilai dan mengukur hasil dari berbagai kegiatan usaha tani yang telah dilakukan. Evaluasi yang dilakukan kelompok tani mufakat yaitu bermusyawarah mengenai berbagai kekurangan yang di hadapi dalam usaha tani , baik kekurangan sarana, prasarana maupun modal. Selain itu kelompok tani mufakat juga berusaha meningkatkan kualitas dan kuantitas dalam usaha tani yang dilaksanakan.

\section{Pembangunan Pertanian}

Pembangunan pertanian dapat diartikan sebagai suatu proses yang ditujukan untuk selalu menambah produksi pertanian untuk tiap-tiap konsumen, yang sekaligus mempertinggi pendapatan dan produktivitas usaha tiap-tiap petani dengan jalan menambah modal dan skill untuk memperbesar turut campur tangannya manusia di dalam perkembangan tumbuhan dan hewan (Hadisapoetro, 2000).

Arifin (2010) mengungkapkan bahwa pembangunan pertanian di Indonesia sebenarnya telah menunjukkan kontribusi yang sukar terbantahkan, bahwa peningkatan produktivitas tanaman pangan melalui varietas unggul, lonjakan produksi peternakan dan perikanan telah terbukti mampu mengatasi persoalan kelaparan dalam empat dasawarsa terakhir. Pembangunan perkebunan dan agroindustri juga telah mampu mengantarkan pada kemajuan ekonomi bangsa, perbaikan kinerja ekspor, dan penyerapan tenaga kerja.

Penyuluhan pertanian adalah sistem pendidikan luar sekolah (orang dewasa) guna menumbuhkembangkan kemampuan (pengetahuan, sikap dan keterampilan) petani nelayan sehingga secara mandiri mereka dapat mengelola unit usaha taninya lebih baik dan menguntungkan sehingga dapat memperbaiki pola hidup yang lebih layak dan sejahtera bagi keluarganya. Kegiatan penyuluhan pertanian sebagai proses belajar bagi petani-nelayan melalui pendekatan kelompok dan diarahkan untuk terwujudnya kemampuan kerja sama yang lebih efektif sehingga mampu menerapkan inovasi, mengatasi berbagai resiko kegagalan usaha, menerapkan skala usaha yang ekonomis untuk memperoleh pendapatan yang layak dan sadar akan peranan serta tanggung jawabnya sebagai pelaku pembangunan, khususnya pembangunan pertanian menurut Djari (2002) dalam Tabloid Agribisnis Dwimingguan Agrina (http://www.agrinaonline.com).

Menurut National Portal Content Management Team (2010), Penyebaran informasi tentang teknologi baru merupakan hal yang pentingsehingga petani dapat menggunakan perkembangan pertanian terkini. Tetapi dalam pelaksanaannya, ada jurang pemisah antara temuan penelitian dan kebutuhan 
petani. Agar teknologi tersebut dapat sukses menyebar di kalangan petani maka sebaiknya teknologi tersebut memberikan tujuan yang berguna bagi pengguna akhirnya. Institusi yang menjembatani jurang pemisah antara petani dan para peneliti dalam bidang pertanian adalah layanan penyuluhan pertanian.

Penyuluhan pertanian didefinisikan sebagai pendidikan nonformal yang ditujukan kepada petani dan keluarganya dengan tujuan jangka pendek untuk mengubah perilaku termasuk sikap, tindakan dan pengetahuan ke arah yang lebih baik, serta tujuan jangka panjang untuk meningkatkan kesejahteraan masyarakat indonesia. Kegiatan penyuluhan pertanian melibatkan dua kelompok yang aktif. Di satu pihak adalah kelompok penyuluh dan yang kedua adalah kelompok yang disuluh.

Menurut Mardikanto (2007), di dalam proses pembangunan pertanian, perbaikan kualitas hidup yang dicita-citakan itu diupayakan melalui kegiatan peningkatan produktivitas usahatani, yakni melalui semakin besarnya turut campur tangan manusia (petani) selama proses produksi berlangsung. Dengan kata lain, pembangunan pertanian menuntut adanya perubahan perilaku petani yang mutlak diperlukan dalam upaya peningkatan produktivitas usahatani dan peningkatan pendapatan demi perbaikan kualitas hidupnya sendiri dan masyarakatnya.

Mosher (2001) memaparkan bahwa pembangunan pertanian cenderung dipikirkan dan dibicarakan hanya karena pembangunan itu menyediakan lebih banyak hasil untuk manusia. Dalam kenyataannya ada terdapat suatu hasil tambahan bahkan barangkali merupakan hasil yang lebih penting, yaitu: pembangunan pertanian mengubah manusia-manusia yang bekerja didalamnya. Supaya pembangunan pertanian itu terlaksana, pengetahuan dan keterampilan para petani haruslah terus meningkat dan berubah. Karena para petani terus-menerus menerima metoda baru, cara berpikir mereka pun berubah. Mereka mengembangkan suatu sikap baru yang berbeda terhadap pertanian, terhadap alam sekitar mereka dan terhadap diri mereka sendiri.

\section{Penyuluhan Pertanian}

Penyuluhan, menurut Van Den Ban (1999), diartikan sebagai keterlibatan seseorang untuk melakukan komunikasi informasi secara sadar dengan tujuan membantu sesamanya memberikan pendapat sehingga bisa membuat keputusan yang benar. Pen- didikan penyuluhan adalah ilmu yang berorientasi keputusan tetapi juga berlaku pada ilmu social berorientasi pada kesimpulan. Ilmu ini mendukung keputusan strategi yang harus diambil dalam organisasi penyuluhan. Penyuluhan juga dapat menjadi sarana kebijaksanaan yang efektif untuk mendorong pembangunan pertanian dalam situasi petani tidak mampu mencapai tujuannya karena keterbatasan pengetahuan dan wawasan. Sebagai sarana kebijakan, hanya jika sejalan dengan kepentingan pemerintah atau organisasi yang mendanai jasa penyuluhan guna mencapai tujuan petani.

Penyuluhan adalah sistem pendidikan luar sekolah di mana orang dewasa dan pemuda belajar dengan mengerjakan. Penyuluhan adalah hubungan kemitraan antara pemeritah, tuan tanah, dan masyarakat, yang menyediakan pelayanan dan pendidikan terencana untuk menemukan kebutuhan masyarakat. Tujuan utamanya adalah kemajuan masyarakat (Kelsey and Cannon, 2001).

Menurut Suhardiyono (2001) penyuluhan merupakan pendidikan non formal bagi petani beserta keluarganya dimana kegiatan dalam ahli pengetahuan dan ketrampilan dari penyuluh lapangan kepada petani dan keluarganya berlangsung melalui proses belajar mengajar. Beberapa ahli penyuluhan menyatakan bahwa sasaran penyuluhan yang utama adalah penyebaran informasi yang bermanfaat dan praktis bagi masyarakat petani di pedesaaan dan kehidupan pertaniannya, melalui pelaksanaan penelitian ilmiah dan percobaan di lapang yang diperlukan untuk menyempurnakan pelaksanaan suatu jenis kegiatan serta pertukaran informasi dan pengalaman diantara petani untuk meningkatkan kesejahteraan mereka.

Menurut Mardikanto (2009) kegiatan penyuluhan diartikan dengan berbagai pemahaman, yaitu seperti: penyebarluasan informasi, penerangan atau penjelasan, pendidikan non formal (luar sekolah), perubahan perilaku, rekayasa sosial, pemasaran inovasi (teknis dan sosial), perubahan social (perilaku individu, nilai-nilai, hubungan antar individu, kelembagaan), pemberdayaan masyarakat (community empowerment), serta penguatan komunitas (community strengthening).

\section{Tujuan Penyuluhan Pertanian}

Pembangunan, apapun pengertian yang diberikan terhadapnya, menurut Mardikanto (2009), selalu merujuk pada upaya perbaikan, terutama perbaikan pada mutu hidup manusia, baik secara fisik, 
mental, ekonomi, maupun sosial budayanya. Terkait dengan pemahaman tersebut, tujuan penyuluhan pertanian diarahkan pada terwujudnya perbaikan teknis bertani (better farming), perbaikan usaha tani (better business), dan perbaikan kehidupan petani dan masyarakatnya (better living).

Menurut Kartasapoetra (1994), dalam perencanaan dan pelaksanaan penyuluhan pertanian harus mencakup: tujuan jangka pendek dan tujuan jangka panjang. Tujuan penyuluhan jangka pendek yaitu untuk menumbuhkan perubahan- perubahan yang lebih terarah dalam aktivitas usaha tani di pedesaan, perubahan-perubahan mana hendaknya menyangkut : tingkat pengetahuan, kecakapan atau kemampuan sikap dan tindakan petani. Adapun tujuan penyuluhan pertanian jangka panjang yaitu agar tercapai peningkatan taraf hidup masyarakat petani, mencapai kesejahteraan hidup yang lebih terjamin. Tujuan ini hanya dapat tercapai apabila petani dalam masyarakat itu, pada umumnya telah melakukan “ better farming, better business, dan better living" yang secara rinci dapat dijelaskan sebagai berikut :

1. Better farming, mau dan mampu mengubah caracara usaha taninya dengan cara-cara yang lebih baik.

2. Better business, berusaha yang lebih menguntungkan, mau dan mampu menjauhi para pengijon, lintah darat, dan melakukan teknik pemasaran yang benar.

3. Better living, hidup lebih baik dengan mampu menghemat, tidak berfoya-foya dan setelah berlangsungnya masa panenan, bias menabung, bekerja sama memperbaiki hygiene lingkungan, dan mampu mencari alternatif lain dalam hal usaha, misal mendirikan industri rumah tangga yang lain dengan mengikutsertakan keluarganya guna mengisi kekosongan waktu selama menunggu panenan berikutnya (Setiana, 2005).

\section{Penyuluh Pertanian}

Penyuluh pertanian adalah orang yang mengemban tugas memberikan dorongan kepada petani agar mau mengubah cara befikir, cara kerja dan cara hidup yang lebih sesuai dengan perkembangan jaman, perkembangan teknologi pertanian yang lebih maju. Dengan demikian seorang penyuluh pertanian dalam melaksanakan tugasnya mempunyai tiga peranan:

a. Berperan sebagai pendidik, memberikan pengetahuan atau cara-cara baru dalam budidaya tana- man agar petani lebih terarah dalam usahataninya, meningkatkan hasil dan mengatasi kegagalankegagalan dalam usaha taninya.

b. Berperan sebagai pemimpin, yang dapat membimbing dan memotivasi petani agar mau merubah cara berfikir, cara kerjanya agar timbul keterbukaan dan mau menerima cara-cara bertani baru yang lebih berdaya guna dan berhasil, sehingga tingkat hidupnya lebih sejahtera.

c. Berperan sebagai penasehat, yang dapat melayani, memberikan petunjuk-petunjuk dan membantu para petani baik dalam bentuk peragaan atau contoh-contoh kerja dalam usahatani memecahkan segala masalah yang dihadapi (Kartasapoetra, 1994).

Dapat dilihat bahwa peran penyuluh sangat berat yang mengharuskannya memiliki kemampuan tinggi. Oleh karena itu, kualitas penyuluh harus terus ditingkatkan sehingga mampu berperan dalam memberikan penyuluhan dan mewujudkan pembangunan pertanian.

\section{Peran Penyuluh}

Sehubungan dengan peran yang menjadi kewajiban dan tanggung jawab setiap penyuluh, Levin (2002) mengenalkan adanya tiga (3) tahapan peran penyuluh yang terdiri atas kegiatan kegiatan :

1. Pencairan diri dengan masyarakat penerima manfaat

2. Menggerakan masyarakat untuk melakukan perubahan

3. Pemantapan hubungan dengan masyarakat penerima manfaat

Selaras dengan peran yang harus dimainkan oleh setiap penyuluh Berlo (2001) mengemukakan empat (4) kualifikasi yang harus dimiliki setiap penyuluh yang mencakup :

1. Kemampuan berkomunikasi, hal ini tidak hanya terbatas pada kemampuan memilih inovasi dan menggunakan media komunikasi yang efektif, memilih dan menerapkan metode komunikasi pembangunan yang efektif dan efisien, memilih dan menggunakan alat bantu dan peraga yang efektif tetapi yang lebih penting adalah kemampuan dan ketrampilan penyuluh untuk berinteraksi dengan masyarakat penerima manfaatnya,

2. Sikap Penyuluh

a. Menghayati dan bangga terhadap profesinya, serta merasakan bahwa ke- 
hadirannya untuk melaksanakan tugas komunikasi pembangunan sangat dibutuhkan masyarakat penerima manfaatnya.

b. Meyakini bahwa inovasi yang disampaikan itu telah teruji kemanfaatannya, memiliki peluang keberhasilan untuk diterapkan pada kondisi alam wilayah kerjanya memberikan keuntungan dan tidak bertentangan dengan nilai - nilai social budaya masyarakat, serta meyakini bahwa inovasi yang akan disampaikan itu benar - benar merupakan kebutuhan nyata meskipun sering kali belum dapat dirasakan masyarakat penerima manfaatnya.

c. Menyukai dan mencintai masyarakat penerima manfaatnya, dalam artian selalu siap memberikan bantuan atau melaksanakan kegiatan - kegiatan demi berlangsungnya perubahan - perubahan usaha tani maupun perubahan masyarakat penerima manfaatnya,

3. Kemampuan penguasaan pengetahuan tentang :

a. Isi, fungsi, manfaat, dan nilai - nilai yang terkandung dalam inovasi yang disampaikan, baik secara konseptual (keilmiahan) maupun secara praktis,

b. Latar belakang dan keadaan masyarakat penerima manfaatnya, baik yang menyangkut perilaku, nilai - nilai social budaya, keadaan alam, maupun kebutuhan - kebutuhan nyata yang di perlukan masyarakat penerima manfaatnya.

c. Segala sesuatu yang seringkali menyebabkan warganya suka atau tidak menghendaki terjadinya perubahan, dan segala sesuatu yang menyebabkan masyarakat seringkali cepat atau lambat mengadopsi inovasi.

4. Karakteristik social budaya penyuluh

Kualifikasi penyuluh tidak cukup hanya dengan memenuhi persyaratan ketrampilan, sikap dan pengetahuan saja, tetapi keadaan latar belakang social budaya (bahasa, agama, kebiasaan - kebiasaan) seringkali lebih banyak menentukan keberhasilan penyuluh yang dilaksanakan. Karena itu, penyuluh yang baik sejauh mungkin harus memiliki latar belakang social budaya yang sesuai dengan keadaan social budaya masyarakat penerima manfaatnya.

\section{Pengertian Gabungan Kelompok Tani (Gapoktan)}

Gabungan Kelompok Tani (Gapoktan) adalah kumpulan dari beberapa kelompok tani yang mempunyai kepentingan yang sama dalam pengembangan komoditas usaha tani tertentu untuk menggalang kepentingan bersama, atau merupakan suatu wadah kerjasama antar kelompok tani dalam upaya pengembangan usaha yang lebih besar (Nasir, 2008).

Menurut Syahyuti (2007) Gapoktan adalah gabungan dari beberapa kelompok tani yang melakukan usaha agribisnis di atas prinsip kebersamaan dan kemitraan sehingga mencapai peningkatan produksi dan pendapatan usahatani bagi anggotanya dan petani lainnya. Penggabungan dalam Gapoktan terutama dapat dilakukan oleh kelompok tani yang berada dalam satu wilayah administrasi pemerintahan untuk menggalang kepentingan bersama secara kooperatif. Wilayah kerja Gapoktan sedapat mungkin di wilayah administratif desa/kecamatan, tetapi sebaiknya tidak melewati batas wilayah kabupaten/kota. Penggabungan kelompok tani ke dalam Gapoktan dilakukan agar kelompok tani dapat lebih berdaya guna dan berhasil guna, dalam penyediaan sarana produksi pertanian, permodalan, peningkatan atau perluasan usaha tani ke sektor hulu dan hilir, pemasaran serta kerja sama dalam peningkatan posisi tawar (Deptan, 2007 ).

\section{Tujuan dan fungsi Gabungan Kelompok Tani (Gapoktan)}

Salah satu ciri terpenting dalam kelompok adalah kesatuan social yang memiliki kepentingan dan tujuan bersama. Tujuan bersama hanya dapat tercapai apabila ada pola interaksi yang mantap dan masing masing individu memiliki perannya masing - masing dan menjalankan peran tersebut. Mardikanto (2007) dalam Setiana (2005) menyebutkan, bahwa ciri-ciri kelompok antara lain adalah memiliki ikatan yang nyata, memiliki interaksi dan interrelasi sesama anggotanya, memiliki struktur dan pembagian tugas yang jelas, memiliki kaidah-kaidah atau norma tertentu yang disepakati, serta memiliki keinginan dan tujuan bersama.

Tujuan utama pembentukan dan penguatan Gapoktan adalah untuk memperkuat kelembagaan petani yang ada, sehingga pembinaan pemerintah kepada petani akan terfokus dengan sasaran yang jelas (Deptan, 2007) dalam Syahyuti (2007). Syahyuti (2007) menambahkan bahwa Gapoktan menjadi lembaga gerbang (gateway institution) yang menjadi 
penghubung petani satu desa dengan lembagalembaga lain di luarnya. Gapoktan diharapkan berperan untuk fungsi-fungsi pemenuhan permodalan pertanian, pemenuhan sarana produksi, pemasaran produk pertanian, dan termasuk menyediakan berbagai informasi yang dibutuhkan petani.

Menurut Deptan (2007) Gapoktan mempunyai fungsi-fungsi,sebagai berikut :

a) Merupakan satu kesatuan unit produksi untuk memenuhi kebutuhan pasar (kuantitas, kualitas, kontinuitas dan harga);

b) Penyediaan saprotan (pupuk bersubsidi, benih bersertifikat, pestisida dan lainnya) serta menyalurkan kepada para petani melalui kelompoknya;

c) Penyediaan modal usaha dan menyalurkan secara kredit/pinjaman kepada para petani yang memerlukan;

d) Melakukan proses pengolahan produk para anggota (penggilingan, grading, pengepakan dan lainnya) yang dapat meningkatkan nilai tambah;

e) Menyelenggarakan perdagangan, memasarkan/ menjual produk petani kepada pedagang/industri hilir.

f) Pengembangan Gabungan Kelompok Tani (Gapoktan).

Menurut Deptan (2007), pengembangan kelompok tani diarahkan pada peningkatan kemampuan setiap kelompok tani dalam melaksanakan fungsinya, peningkatan kemampuan para anggota dalam mengembangkan agribisnis, penguatan kelompok tani menjadi organisasi petani yang kuat dan mandiri. Kelompok tani yang berkembang bergabung ke dalam Gabungan Kelompok Tani (GAPOKTAN). Peningkatan kemampuan Gapoktan dimaksudkan agar dapat berfungsi sebagai unit usahatani, unit usaha pengolahan, unit usaha sarana dan prasarana produksi, unit usaha pemasaran dan unit usaha keuangan mikro serta unit jasa penunjang lainnya sehingga menjadi organisasi petani yang kuat dan mandiri (Departemen Pertanian, 2007).

Gapoktan dapat dikatakan sebagai suatu kelembagaan transisional antara lembaga sosial petani menjadi lembaga sosialekonomi petani. Sesuai dengan namanya Gapoktan merupakan gabungan dari beberapa kelompok tani, yang dengan adanya penggabungan ini menyebabkan skala usaha menjadi lebih besar se- hingga lebih mudah dalam mencapai tingkat efisiensi yang lebih baik. Sebagai sebuah lembaga sosial ekonomi petani, gapoktan memiliki ciri adanya kohesivitas yang kuat antara petani/kelompoktani anggotanya, dan disamping itu adanya unit usaha bersama yang dimiliki bersama para anggota untuk kepentingan bersama dan dikontrol bersama secara demokratis (Setiana, 2005).

Ciri - ciri Gapoktan yang kuat dan mandiri menurut Deptan (2007) adalah sebagai berikut :

a) Adanya pertemuan/rapat anggota/rapat pengurus yang diselenggarakan secara berkala dan berkesinambungan.

b) Disusunannya rencana kerja gapoktan secara bersama dan dilaksanakan oleh para pelaksana sesuai dengan kesepakatan bersama dan setiap akhir pelaksanaan dilakukan evaluasi secara partisipasi.

c) Memiliki aturan/norma tertulis yang disepakati dan ditaati bersama.

d) Memiliki pencatatan/pengadministrasian setiap anggota organisasi yang rapih.

e) Memfasilitasi kegiatan-kegiatan usaha bersama di sektor hulu dan hilir.

f) Memfasilitasi usaha tani secara komersial dan berorientasi pasar.

g) Sebagai sumber serta pelayanan informasi dan teknologi untuk usaha para petani umumnya dan anggota kelompok tani khususnya.

h) Adanya jalinan kerjasama antara Gapoktan dengan pihak lain.

i) Adanya pemupukan modal usaha baik iuran dari anggota atau penyisihan hasil usaha/kegiatan Gapoktan.

Menurut Deptan (2007) pengembangan kelompok tani dan Gapoktan diselenggarakan disemua tingkatan yaitu tingkat desa, tingkat kecamatan, tingkat kabupaten/kota, tingkat provinsi dan tingkat pusat.

Pada tingkat desa penanggung jawab pengembangan kelompok tani adalah kepala Desa, sedangkan operasionalnya dilaksanakan oleh penyuluh pertanian yang bertugas di wilayah tersebut dengan kegiatan-kegiatan, yaitu:

a) Menghadiri pertemuan/musyawara yang diselengarakan oleh kelompok tani.

b) Menyampaikan berbagai informasi dan teknologi usaha tani. 
c) Memfasilitasi kelompok tani dalam melakukan PRA, penyusunan rencana defintif kelompok (RDK) dan rencana definitif kebutuhan kelompok (RDKK).

d) Penyususnan program penyuluhan pertanian desa/kelurahan.

e) Mengajarkan berbagai ketrampilan usaha tani serta melakukan bimbingan penerapannya.

f) Membantu para petani untuk mengidentifikasi permasalahan usaha tani.

g) Menginventarisir masalah-masalah yang tidak dapat dipecahkan oleh kelompok tani dan anggota untuk dibawah pertemuan di BPP.

h) Melakukan pencatatan mengenai keanggotaan dan kegiatan kelompok tani yang tumbuh dan berkembang diwilayah kerjanya.

i) Menumbuh kembangakan kemampuan menajerial, kepemimpinan, dan kewirausahaan kelembagaan tani serta pelaku agribisnis lainnya.

j) Memfasilitasi terbentuknya gabungan kelompok tani serta pembinaannya.

k) Melaksanakan forum penyuluhan tingkat desa (musyawarah/rembug kontak tani, temu wicara serta koordinasi penyuluhan pertanian).

Gabungan kelompok tani (Gapoktan) merupakan organisasi petani perdesaan yang dibentuk secara musyawarah dan mufakat untuk meningkatkan skala ekonomi dan efisiensi usaha. Gapoktan dibentuk atas dasar: (1) kepentingan yang sama diantara para anggotanya; (2) berada pada kawasan usahatani yang menjadi tanggung jawab bersama diantara para anggotanya; (3) mempunyai kader pengelola yang berdedikasi untuk mengerakan para petani; (4) memiliki kader atau pemimpin diterima oleh petani lainnya; (5) mempunyai kegiatan yang dapat dirsakan manfaatnya oleh sebagian besar anggotanya, dan (6) adanya dorongan atau motivasi dari tokoh masyarakat setempat. Untuk membangun Gapoktan yang ideal sesuai dengan tuntutan organisasi masa depan, diperlukan dukungan sumber daya manusia yang berkualitas melalui pembinaan yang berkelanjutan. Proses penumbuhan dan pengembangan gapoktan yang kuat dan mandiri diharapkan secara langsung dapat menyelesaikan permasalahan petani dalam pembiayaan, dan pemasaran. Berdasarkan peraturan Menteri Per- tanian Nomor 273/Kpts/OT.160/4/2007 tentang pedoman pembinaan kelembagaan petani, pembinaan kelompok tani diarahkan pada penerapan system agribisnis, peningkatan peranan, peran serta petani dan anggota masyarakat perdesaan (Kementrian Pertanian, 2010).

Gapoktan dapat dikatakan sebagai suatu kelembagaan transisional antara lembaga sosial petani menjadi lembaga sosialekonomi petani. Sesuai dengan namanya Gapoktan merupakan gabungan dari beberapa kelompoktani, yang dengan adanya penggabungan ini menyebabkan skala usaha menjadi lebih besar sehingga lebih mudah dalam mencapai tingkat efisiensi yang lebih baik. Sebagai sebuah lembaga sosial ekonomi petani, gapoktan memiliki ciri adanya kohesivitas yang kuat antara petani/kelompoktani anggotanya, dan disamping itu adanya unit usaha bersama yang dimiliki bersama para anggota untuk kepentingan bersama dan dikontrol bersama secara demokratis (Feryanto William, 2007). Pengembangan Gapoktan dilatarbelakangi oleh kenyataan kelemahan aksesibilitas petani terhadap berbagai kelembagaan layanan usaha, misalnya lemah terhadap lembaga keuangan, terhadap lembaga pemasaran, terhadap lembaga penyedia sarana produksi pertanian, serta terhadap sumber informasi. Pada prinsipnya, lembaga Gapoktan diarahkan sebagai sebuah kelembagaan ekonomi, namun diharapkan juga mampu menjalankan fungsi-fungsi lainnya.

Penyuluh bertugas menyampaikan hasil temuan lembaga penelitian kepada petani. Sebaliknya, petani berkewajiban melaporkan pelaksanaan penerapan hasil temuan lembaga penelitian yang dianjurkan tersebut sebagai penghubung, selanjutnya penyuluh menyampaikan hasil penerapan teknologi yang dilakukan oleh petani kepada lembaga penelitian yang terkait sebagai bahan referensi lebih

Lanjut Peranan dari penyuluh pertanian sebagai fasilitator, motivator dan sebagai pendukung gerak usaha petani merupakan titik sentral dalammemberikan penyuluhan kepada petani - nelayan akan pentingnya berusaha tani dengan memperhatikan kelestarian dari sumber daya alam. Kesalahan dalam memberikan penyuluhan kepada petani - nelayan akan menimbulkan dampak negatif dan merusak lingkungan. Proses penyelenggaraan penyuluhan pertanian dapat berjalan dengan baik dan benar apabila didukung dengan tenaga 
penyuluh yang profesional, kelembagaan penyuluh yang handal, materi penyuluhan yang terusmenerus mengalir, sistem penyelenggaraan penyuluhan yang benar serta metode penyuluhan yang tepat dan manajemen penyuluhan yang polivalen. Dengan demikian penyuluhan pertanian sangat penting artinya dalam memberikan modal bagi petani dan keluargannya, sehingga memiliki kemampuan menolong dirinya sendiri untuk mencapai tujuan dalam memperbaiki kesejahteraan hidup petani dan keluarganya, tanpa harus merusak lingkungan di sekitarnya. Tugas seorang Penyuluh Pertanian Lapangan (PPL) adalah meniadakan hambatan yang dihadapi seorang petani dengan cara menyediakan informasi dan memberikan pandangan mengenai masalah yang dihadapi. Informasi tentang pengelolaan sumber daya alam dengan teknologi yang baik dan benar sesuai dengan kondisi lahan sangat bermanfaat bagi petani - nelayan untuk meningkatkan hasil produksinya tanpa harus merusak lingkungan usaha taninya sehingga dapat meminimalisir degradasi lahan dan kerusakan lingkungan pada umumnya.

Menurut Kartasapoetra (1994) pada setiap Wilayah Kerja Penyuluhan Pertanian (WKPP) ditetapkan seorang petugas PPL (penyuluh pertanian lapang) yang akan mengemban tugas pokok sebagai berikut :

1) Menyebarkan informasi pertanian yang bermanfaat

2) Mengajarkan ketrampilan yang lebih baik

3) Memberikan saran-saran atau rekomendasi bagi usaha tani yang lebih menguntungkan

4) Membantu mengikhtiarkan sarana produksi, fasilitas kerja serta bahan informasi pertanian yang diperlukan para petani

5) Mengembangkan swakarya dan swasembada para petani agar taraf kehidupannya dapat lebih meningkat.

\section{Rumusan Masalah}

Bagaimana partisipasi kelompok tani dalam kegiatan penyuluhan pertanian di Desa Kanonang Lima Kecamatan Kawangkoan Barat.

\section{Tujuan dan Manfaat Penelitian}

Tujuan penelitian yaitu mendeskripsikan partisipasi kelompok tani dalam kegiatan penyuluhan di Desa Kanonang Lima Kecamatan Kawangkoan Barat.

Manfaat penelitian ini diharapkan dapat menjadi sumbangan ilmu pengetahuan bagi penyuluh pertanian di Desa Kanonang Lima Kecamatan Kawangkoan Barat.

\section{METODOLOGI PENELITIAN}

\section{Waktu dan Tempat Penelitian}

Penelitian ini berlangsung selama tiga bulan sejak persiapan sampai penyusunan laporan terhitung dari Bulan Juli sampai September 2015. Penelitian ini dilaksanakan di Desa Kanonang Lima Kecamatan Kawangkoan Barat Kabupaten Minahasa.

\section{Metode Pengumpulan Data}

Penelitian menggunakan metode purposive sampling dari satu gapoktan ada empat kelompok tani yaitu kelompok tani Esa Lalan, Esa Ate, Karondoran dan Berkat yang berada di Desa Kanonang Lima Kecamatan Kawangkoan Barat. Yang diambil hanya dua kelompok tani yang menonjol yaitu kelompok tani Esa Lalan dan kelompok tani Esa Ate. Metode pengumpulan data dilakukan dengan menggunakan dengan data primer. Data primer diperoleh langsung dari kelompok tani Esa Lalan dan kelompok tani Esa Ate menggunakan daftar pertanyaan (kuesioner).

\section{Konsep Pengukuran Variabel}

Variabel-variabel yang dikaji dalam penelitian ini adalah :

1. Perencanaan kelompok (yang dilihat dari jumlah petani) partisipasi petani dalam kehadiran pada pertemuan. Berdasarkan survei frekuensi dalam pertemuan dilihat dari jenis usaha padi sawah yaitu 6 kali pertemuan dimulai dari penentuan lokasi dan benih.

$$
\begin{aligned}
1-2 & =\text { Tidak Aktif }(1) \\
3-4 & =\text { Kurang Aktif }(2) \\
5-6 & =\text { Aktif (3) }
\end{aligned}
$$

2. Pelaksanaan kegiatan didalam kelompok Pelaksanaan kegiatan didalam kelompok (keaktifan partisipasi pelaksanaan kegiatan kerja diukur berdasarkan kegiatan dalam satu musim panen 3 kali dalam pelaksanaan, keaktifan anggota ke- 
lompok tani dalam kegiatan kerja kelompok) yang dikategorikan dalam 3 tingkat yaitu :

Tidak Aktif (1 tidak pernah hadir)

Kurang Aktif (2 kali hadir)

Aktif (3 kali hadir)

3. Keaktifan dalam memberi masukan atau pendapat dalam evaluasi (sebanyak 6 kali) memberi masukan/ pendapat dalam evaluasi kelompok tani diukur berdasarkan peneliti terhadap keaktifan partisipasi anggota dalam evaluasi yang dikategorikan dalam 3 tingkat yaitu :

$$
\begin{aligned}
& 1-2=\text { Tidak Aktif (1) } \\
& 3-4=\text { Kurang Aktif (2) } \\
& 5-6=\text { Aktif (3) }
\end{aligned}
$$

\section{Metode Analisis Data}

Metode analisis data yang digunakan adalah analisis data kualitatif dimana metode ini mendiskripsikan partisipasi kelompok tani dalam kegiatan penyuluhan pertanian.

\section{HASIL DAN PEMBAHASAN}

\section{Letak dan Luas Wilayah}

Desa Kanonang Lima adalah salah satu Desa di Kecamatan Kawangkoan Barat, Dengan luas wilayah 120 Ha yang terdiri dari 7 lingkungan. Adapun batas-batas Desa sebagai berikut :

1. Sebelah Utara : Kanonang Satu

2. Sebelah Selatan: Kanonang Empat

3. Sebelah Barat : Tombasian atas

4. Sebelah Timur : Pinabetengan

\section{Jumlah Penduduk}

Secara umum penduduk Desa Kanonang Lima berjumlah 2849 jiwa yang terdiri dari 769 Kepala keluarga (KK) dimana jumlah penduduk laki-laki 1480 jiwa dan perempuan 1369 jiwa.

\section{Mata Pencarian}

Masyarakat di Desa Kanonang Lima Kecamatan Kawangkoan Barat memiliki mata pencarian sebagai petani, pegawai negeri, TNI/POLRI, wiraswasta, pedagang, dan lain-lain.
Tingkat Pendidikan

Tingkat pendidikan Desa Kanonang Lima berdasarkan data monografi statistic desa rata-rata SD, SMP, SMA, sedangkan jumlah lulusan perguruan tinggi masih sangat kurang.

\section{Umur}

\section{Karakteristik Responden}

Kemampuan bekerja atau melakukan aktifitas secara fisik bahkan cara berpikir seseorang sangat dipengaruhi oleh faktor umur. Demikian pula halnya dengan petani dalam melakukan pekerjaannya, petani yang berumur dibawah 40 tahun akan bekerja lebih efektif dibandingkan petani yang berumur diatas 40 tahun. Hal ini disebabkan karena petani yang umurnya lebih muda yaitu dibawah 40 tahun secara fisik lebih kuat dan sehat dibandingkan petani yang berumur tua yaitu diatas 40 tahun.

Tabel 1 menunjukkan bahwa umur $31-40$ tahun menunjukan persentase yaitu sebanyak 7 responden (33,33 persen) di kelompok tani Esa Lalan, dimiliki juga dengan kelompok tani Esa Ate sebanyak 11 responden (55 persen) petani berada pada kelompok usia ini, sedangkan anggota kelompok tani yang berusia muda dan produktif tidak ada, dibandingkan dengan usia yang lebih tua dan tidak produktif yaitu 31-71 tahun.

\begin{tabular}{|c|c|c|c|}
\hline \multirow[b]{2}{*}{ No } & \multicolumn{3}{|c|}{ Kelompok Tani } \\
\hline & Umur & Esa Lalan $(\%)$ & Esa Ate $(\%)$ \\
\hline 1 & $31-40$ & $7 \quad(33,33)$ & $11 \quad(55)$ \\
\hline 2 & $41-50$ & $6 \quad(19,04)$ & $(19,04)$ \\
\hline 3 & $51-60$ & $4 \quad(19,04)$ & $2 \quad(10)$ \\
\hline 4 & $61-70$ & $3 \quad(14,28)$ & $2 \quad(10)$ \\
\hline 5 & $71-80$ & $1 \quad(4,76)$ & $1 \quad(4,76)$ \\
\hline & Jumlah & $21(100)$ & $20 \quad(100)$ \\
\hline
\end{tabular}

Tabel 1. Distribusi Responden menurut Umur Anggota Kelompok Tani

\section{Tingkat Pendidikan}

Peranan pendidikan formal sangat penting dalam usaha peningkatan kualitas penduduk karena berguna dalam pembangunan pribadi serta peningkatan intelektual dan wawasan seseorang. Berdasarkan hasil penelitian, tingkat pendidikan responden bervariasi mulai dari tingkat Sekolah Dasar (SD) sampai sekolah Menengah Atas (SMA)/sederajat. Hal ini dapat dilihat pada Tabel 2 . 
Tabel 2. Distribusi Anggota menurut Tingkat Pendidikan

\begin{tabular}{|llcccl|}
\hline \multicolumn{5}{|c|}{ No Pendidikan Kelompok Tani } & Jumlah \\
Esa Lalan & Esa Ate & \\
\hline 1 & SD & 7 & 4 & 11 & 27,5 \\
2 & SMP & 3 & 12 & 14 & 35 \\
3 & SMA & 10 & 4 & 14 & 35 \\
4 & S1 & 1 & 0 & 1 & 2,5 \\
\hline & Jumlah & 21 & 20 & 40 & 100 \\
\hline
\end{tabular}

Sumber: Diolah dari data primer, 2015

Tabel 2 Menunjukkan semua responden yang merupakan anggota kelompok tani pernah mengikuti pendidikan formal. Tingkat pendidikan paling tinggi yang pernah diikuti adalah S1 yaitu sebanyak 1 responden (2,5 persen), sedangkan tingkat pendidikan yang paling banyak ditempuh adalah SMP dan SMA yaitu sebanyak 14 responden (35 persen) yang tidak berada jauh dengan tingkat pendidikan SD yaitu sebanyak 11 responden atau 27,5 persen.

\section{Luas Lahan}

Luas lahan yang diusahakan petani akan mempengaruhi besarnya pendapatan petani itu sendiri. Apabila semakin besar lahan yang diushakan oleh petani maka semakin besar pula jumlah produksi dan pendapatan yang akan dihasilkan. Luas lahan, luas panen kelompok tani Esa Lalan dan Esa Ate berkisar 0,5 sampai 2 dengan rata-rata kepemilikan lahan 0,5-2 Ha.

Berdasarkan pada Tabel 3, dapat dikatakan kelompok tani Esa Lalan semua anggotanya yang paling banyak mengusahakan lahan seluas 1-1,5 Ha yaitu 15 responden (71,42 persen), sedangkan Esa Ate anggotanya yang paling banyak mengusahakan lahan seluas $2 \mathrm{Ha}$ atau sebanyak 8 responden atau 40 persen.

Tabel 3. Distribusi Responden Berdasarkan Strata Luas Lahan

\begin{tabular}{|llllll|}
\hline No & \multicolumn{3}{c}{$\begin{array}{c}\text { Strata Luas Lahan } \\
\text { (Ha) }\end{array}$} & \multicolumn{3}{c|}{ Jumlah Responden (Org) } \\
Esa Lalan(\%) & Esa Ate(\%) \\
\hline 1 & 0,5 & 4 & $(19,04)$ & 6 & $(30)$ \\
2 & $1-1,5$ & 15 & $(71,42)$ & 6 & $(30)$ \\
3 & 2 & 2 & $(9,52)$ & 8 & $(40)$ \\
\hline & Jumlah & 21 & 100 & 20 & 100 \\
\hline
\end{tabular}

Sumber: Diolah dari data primer, 2015

\section{Partisipasi kelompok tani dalam Penyuluhan Pertanian}

\section{Kehadiran kelompok tani dalam pertemuan dalam satu musim panen)}

Pada Tabel 4 menjelaskan tentang distribusi anggota kelompok tani menurut tingkat kehadiran dalam pertemuan kelompok dalam satu musim panen.

Dengan melihat persentase pada Tabel 4, dapat dikatakan bahwa kehadiran anggota kelompok tani Esa Lalan sebesar 16 responden atau 71,42 persen anggota yang aktif dalam penyuluhan pertanian 16 orang dari jumlah Responden, dan kurang aktif $19,04 \%$ atau 4 orang. Sedangkan tidak aktif 4,76\% atau 1 orang.

Tabel 4. Partisipasi Kelompok Tani menurut Kehadiran dalam penyuluhan pertanian

\begin{tabular}{|llrc|}
\hline \multirow{2}{*}{ No } & Tingkat Partisipasi & $\begin{array}{c}\text { Kelompok Tani } \\
\text { Esalan }\end{array}$ & $\begin{array}{c}\text { Esa Ate } \\
(\%)\end{array}$ \\
\hline 1 & Aktif & $16(71,42)$ & $10(50)$ \\
2 & Kurang Aktif & $4(19,04)$ & $6(30)$ \\
3 & Tidak Aktif & $1(4,76)$ & $4(20)$ \\
\hline & Jumlah & $21(100)$ & $20(100)$ \\
\hline
\end{tabular}

Sumber: Diolah dari Data Primer, 2015

Demikian dengan anggota kelompok tani Esa Ate memiliki 10 responden atau 50 persen anggota yang aktif dalam penyuluhan pertanian atau sebesar 6 responden atau 30 persen, tidak aktif sebanyak 4 responden atau 20 persen. 'Seperti yang disampaikan oleh salah satu pengurus kelompok tani Esa Lalan mengatakan bahwa kehadiran dalam penyuluhan pertanian untuk satu musim panen masih ada atau tidak aktif.

Selanjutnya yang disampaikan salah satu pengurus aktif anggota kelompok tani Esa Ate mengatakan bahwa kurangnya kehadiran dalam penyuluhan pertanian Esa Ate karena kebanyakan dari mereka memiliki pekerjaan lain seperti tukang ojek dan penjaga kios sehingga tidak hadir dalam pertemuan, padahal pertemuan sangat penting.

\section{Pelaksanaan kegiatan}

Pada Tabel 5 menjelaskan tentang distribusi anggota kelompok tani menurut tingkat keaktifan dalam pelaksanaan kegiatan. 


\begin{tabular}{|c|c|c|c|c|}
\hline \multirow[b]{2}{*}{ No } & \multirow[b]{2}{*}{ Tingkat Partisipasi } & \multicolumn{3}{|c|}{ Kelompok Tani } \\
\hline & & & $\begin{array}{c}\text { Esa Lalan } \\
(\%)\end{array}$ & $\begin{array}{c}\text { Esa Ate } \\
(\%)\end{array}$ \\
\hline 1 & Aktif & & $(85,71)$ & $14(70)$ \\
\hline 2 & Kurang Aktif & 2 & $(9,52)$ & $5(25)$ \\
\hline 3 & Tidak Aktif & 1 & $(4,76)$ & $1(4,76)$ \\
\hline & Jumlah & 21 & $(100)$ & $20(100)$ \\
\hline
\end{tabular}

Sumber: Diolah dari data primer, 2015

Tabel 5 menunjukkan bahwa anggota kelompok tani Esa Lalan memiliki 85,71 persen atau 18 responden anggota yang aktif dalam kegiatan, dan kurang aktif 9,52 persen atau 2 responden. Sedangkan tidak aktif 4,76 persen atau 1 responden.

Pelaksanaan anggota kelompok tani Esa Ate memiliki 70 persen anggota yang aktif dalam pelaksanaan kegiatan atau 14 responden, kurang aktif 4,76 persen atau 1 responden, sedangkan tidak aktif 4,76 persen atau 1 responden.

Seperti yang disampaikan oleh salah penggurus dari kelompok tani bukan responden yang tidak pernah aktif dalam kegiatan pelaksanaan kelompok banyak urusan diluar kelompok tani, tapi mereka telah minta ijin dari ketua klompok.

Demikian pula pada salah satu penggurus anggota kelompok tani Esa Ate mengatakan bahwa kami hanya sebagian aktif dalam kegiatan kelompok, sehingga masih sedikit kegiatan didalam kelompok karena kami sebagai pengurus yang sangat tahu keadaan kelompok tani, dan mereka yang kurang aktif dalam kegiatan kelompok itu karena kebanyakan dari mereka adalah umurnya sudah tua.

\section{Keaktifan Dalam Memberi Masukan/Pendapat Dalam Evaluasi}

Tabel 6 akan menunjukan keaktifan dalam memberi masukan atau pendapat dalam evaluasi, sehingga dapat dilihat pada tingkat anggota kelompok dalam evaluasi.

Tabel 6 menunjukkan dikatakan bahwa anggota kelompok tani Esa Lalan memiliki 52,38 persen atau 11 responden anggota yang aktif dalam kegiatan evaluasi, dan kurang aktif 28,57 persen atau 6 orang, tidak aktif 19,04 persen atau 4 responden.

Demikian dengan anggota kelompok tani Esa Ate memiliki 25 persen atau 5 responden yang aktif dalam evaluasi kegiatan, Kurang aktif 65 persen atau 13 responden sedangkan tidak aktif 10 persen atau 2 responden.

Tabel 6. Jumlah Responden "Esa Lalan dan Esa Ate" yang memberikan Pendapat Dalam Evaluasi

\begin{tabular}{|llcccc|}
\hline & & \multicolumn{4}{c|}{ Kelompok Tani } \\
No & Tingkat Partisipasi & Esa Lalan(\%) & Esa Ate( \%) \\
\hline 1 & Aktif & 11 & $(52,38)$ & 5 & $(25)$ \\
2 & Kurang Aktif & 6 & $(28,57)$ & 13 & $(65)$ \\
3 & Tidak Aktif & 4 & $(19,04)$ & 2 & $(10)$ \\
\hline & Jumlah & 21 & $(100)$ & 20 & $(100)$ \\
\hline
\end{tabular}

Sumber: Diolah dari data primer, 2015

Keaktifan memberi masukan atau pendapat dalam evaluasi, menurut anggota kelompok tani Esa Lalan sebagian aktif dalam evaluasi karena reponden sangat kurang aktif dalam memberi masukan atau pendapat dalam evaluasi itu semua karena dipengaruhi tingkat pendidikan yang rendah, artinya hanya sampai pada tingkat SD. Seperti yang disampaikan salah satu penggurus yang selalu aktif memberi masukan atau pendapat dalam evaluasi anggota kelompok tani Esa Ate mengatakan bahwa sedikitnya masukan atau pendapat dalam evaluasi karena tingkat kehadiran dalam kelompok masih sedikit, karena kesibukan pribadi.

Dari Tabel 7 menunjukkan bahwa partisipasi pertanian tahap tinggi, pada tahap pelaksanaan dengan partisipasi keaktifan sebesar 77,90 persen, dilihat tahap perencanaan sebesar 63,10 persen dan evaluasi sebesar 38,69. Secara keseluruhan partisipasi petani dapat dilihat sangat aktif.

Tabel 7. Persentase Partisipasi Petani dalam Kegiatan Penyuluhan Pertanian

\begin{tabular}{|lccc|}
\hline Tahap & Aktif & Kurang Aktif & Tidak Aktif \\
\hline Perencanaan & 63,10 & 24,52 & 12,38 \\
Pelaksanaan & 77,90 & 17,30 & 4,80 \\
Evaluasi & 38,69 & 46,79 & 14,52 \\
\hline
\end{tabular}

Sumber: Diolah dari data primer, 2015

\section{KESIMPULAN DAN SARAN}

\section{Kesimpulan}

Berdasarkan hasil penelitian ditemukan bahwa tingkat partisipasi terhadap kelompok tani Esa Lalan tergolong pada kategori yang aktif, hal ini dilihat dari keaktifan anggota kelompok tani dalam kegiatan program penyuluh yaitu: 
1. Kehadiran dalam pertemuan kelompok dalam satu musim panen

2. Pelaksanaan kegiatan didalam kelompok

3. Keaktifan dalam memberi masukan ide/pendapat dalam evaluasi

4. Keterlibatan/keikutsertaan dalam setiap kegiatan Gapoktan

5. Pertemuan dengan Instansi Terkait (PPL, aparat pemerintah)

\section{Saran}

Perlu adanya peningkatan atau harus dimaksimalkan lagi peranan penyuluh pertanian terhadap kedua kelompok tani.

\section{DAFTAR PUSTAKA}

Arifin, Bustanul. 2010. Strategi Baru Pembangunan Pertanian. http://tkpkri.org/berita/berita/ strategi-barupembangunan-pertanian.html. Diakses pada tanggal 15 September 2015.

Djari (2002) dalam Tabloid Agribisnis Dwimingguan Agrina (http://www.agrina-online.com).

Departemen Pertanian. 2007. Pedoman Pembinaan Kelembagaan Petani. http://www.deptan.go.id/bpsdm/peraturan/Perment an\%20273-2007\%20Lampiran\%201.PDF. Diakses pada tanggal 9 September 2015.

Hadisapoetro, Soedarsono. 2000. Pembangunan Pertanian. Departemen Ekonomi Pertanian Fakultas Pertanian UGM. Yogyakarta.

Kartasapoetra, A. G. 1994. Teknologi Penyuluhan Pertanian. Bumi Aksara. Jakarta.

Kementrian Pertanian. 2010. Petunjuk Teknis Pemeringkatan (Rating) Gapoktan PUAP menuju LKM-A. http://www.google. co.id. Diakses pada tanggal 10 September 2015.

Kelsey, LD and Cannon CH. 2001. Cooperative Extension Work. Comstock Publishing Associates. New York.

Levin (2002) Mengenalkan Adanya Tiga (3) Tahapan Peran Penyuluh

Mardikanto, Totok. 2009. Penyuluhan Pembangunan Pertanian.UNS Press. Surakarta.

Mikkelsen (2003), Mendefinisikan Partisipasi adalah Sukarela oleh Masyarakat dalam Perubahan yang Ditentukannya Sendiri.

Mosher, AT. 2001. Menggerakkan dan Membangun Pertanian: Syarat-syarat PokokPembangunan dan Modernisasi Cetakan Ketigabelas. CV Yasaguna.
Diterbitkan dengan Kerjasama Franklin Book Programs, Inc. New York.

Jakarta.

Mushero, Heroni. 2008. Pemberdayaan Petani Melalui Gabungan Kelompok Tani (GAPOKTAN). http://heronimushero.wordpress.com/2008/03/05/p emberdayan-petani-melalui-gabungan-kelompoktani-gapoktan/. Diakses pada tanggal 5 September 2015.

Nasir. 2008. Pengembangan Dinamika Kelompok

Tani. http://www.dispertanak. pandeglang.go.id /artikel_11.htm. Diakses pada tanggal 19 Agustus 2015. National Portal Content Management Team (2010).

Porawouw, 2005.Meningkatkan Pendapatan Dan Pengembangan

Syahyuti. 2007. Strategi dan Tantangan dalam Pengembangan Gabungan

Kelompok Tani (GAPOKTAN) sebagai Kelembagaan Ekonomi di Pedesaan. http://www.geocities. com /syahyuti/Gapoktan.pdf. Diakses pada tanggal 28 Agustus 2015.

Suhardiyono, L. 2001. Penyuluhan : Petunjuk Bagi Penyuluh Pertanian. Erlangga. Jakarta.

Setiana, Lucie. 2005. Teknik Penyuluhan dan Pem berdayaan Masyarakat. Ghalia. Indonesia. Bogor.

Sutami, 2009 Jenis-Jenis Partisipasi

Sastroepoetra, 2004. Partisipasi adalah keterlibatan spontan dengan kesadaran

Tabloid Agribisnis Dwimingguan Agrina. 2010. Peranan penyuluh pertanian. http://www.agrina-online.com. Diakses pada tanggal 20 Agustus 2015.

Van Den Ban dan Hawkins . 1999. Penyuluhan Pertanian. Kanisius. Yogyakarta. 